\title{
26-ESKADER R.F.C.
}

Onder die opskrif 1915-1918 is, in die gedenkboek Per aspera ad astra 1920-1970, 'n aantal bladsye aan 26-Eskader R.F.C. gewy en o.m. verklaar dat die Britse regering met die toenmalige Statebondslande ooreengekom het om alle afsonderlike Lugmag-eenhede by die Royal Flying Corps (R.F.C.) in te lyf. Vervolgens is verwys na 'n skrywe wat op 21 Augustus 1915 deur die War Office aan die Koloniale Ondersekretaris gerig is en waarin die gedagte uitgespreek is om ' $n$ eenheid, bestaande uit Suid-Afrikaanse personeel, m.a.w. die stigting van 'n suiwer Suid-Afrikaanse eskader van die R.F.C., te oorweeg.

In werklikheid het die Unieregering reeds op 9 Julie 1915 aan die Imperiale regering aangebied om die volledige Z.A.V.K., m.a.w. personeel en toerusting, ter beskikking van die Imperiale regering te stel.

Met hierdie aanbod begin die voorgeskiedenis van die latere 26-Eskader R.F.C./R.A.F. waarvan nou die volgende besonderhede verstrek word.

1 Die Unieregering se aanbod t.o.v. die Z.A.V.K. aan die Imperiale regering

Op 9 Julie 1915 het die Departement van Verdediging 'n kodetelegram aan die Hoë Kommissaris in Londen gestuur, waarin aangebied is om die volledige Z.A.V.K. ter beskikking van die Imperiale regering te stel. Tewens is verklaar dat die personeel en toerusting binne 3 weke op Walvisbaai ingeskeep kan word. Verder is vermeld dat die Unieregering nie oor parlementêre tosstemming beskik om fondse buitekant die Unie uit te gee nie. Bygevolg sal, vanaf die inskeping op Walvisbaai, die Imperiale regering alle koste, teen Imperiale tariewe, moet dra terwyl die Britse admiraliteit die vervoer sal moet reël. Met betrekking tot die vliegtuie is die Unieregering bereid om die bruikbare Henri Farman-vliegtuie en toerusting teen 'n redelike prys aan die Britse admiraliteit te verkoop. Hieraan is toegevoeg dat die koste van die Suidwes-veldtog vermoedelik hoër sal wees as die bedrag wat in dié verband goedgekeur is. Bygevolg is die finansiële toestand ernstig. Dit word vermy om die parlement spesiaal bymekaar te roep om die ekstra-uitgawes goed te keur, maar andersyds word daar vanselfsprekend geen druk op die Imperiale regering uitgeoefen om die vliegtuie en toerusting terug te koop nie.

Op dieselfde dag lig die Minister van Verdediging die opperbevelhebber (genl. L. Botha) op Otavifontein per kodetelegram oor die inhoud van bogenoemde kodetelegram in.

Op hierdie tydstip was die sterkte van die Z.A.V.K. 152, waarvan 120 by die eintlike lugvaartseksie van die korps en 32 by die transportseksie ingedeel was. Eersgenoemde seksie het uit 1 eskaderleier (kapt./tydelike maj.) G. P. Wallace), 1 vlugbevelvoerder, 1 mediese offisier, 1 adjudant, 3 vlieëniers, 3 waarnemers (offisiere), 1 offisier in bevel van die vliegtuigpark, 1 sersant-majoor, 3 vlugsersante, 10 sersante, 6 korporaals en 67 manskappe (le en 2e klas lugwerktuigkundiges), 1 assistent-kok, e.d.m. en 22 nie-Blankes bestaan. Die transportseksie was soos volg saamgestel: 1 offisier, 2 stafsersante, 4 sersante, 4 korporaals en 20 manskappe (1e en 2e klas lugwerktuigkundiges).

Op 9 Julie 1915 het genl. Botha van Otavifontein geantwoord:

Have instructed avion and wait return from Walvis and communicate direct with you as to future movements. 
Terselfdertyd is maj. G. P. Wallace gelas om na Walvisbaai terug te keer en regstreeks met genl. Smuts in verbinding te bly t.o.v. toekomstige bewegings of opdragte.

'n Dag later het maj. Wallace van Otjiwarongo berig dat die korps nou na Walvisbaai terugkeer. In dieselfde telegram versoek hy om na Pretoria oor te kom ten einde die toekoms van die Z.A.V.K. te kan bespreek en dat 'n antwoord op sy versoek na Omaruru gestuur word. Aan hierdie versoek is voldoen. Maj. Wallace het op 12 Julie van Omaruru na Walvisbaai vertrek en, saam met kapt. K. R. van der Spuy, op 13 Julie van Walvisbaai na Kaapstad afgereis waar hulle op 16 Julie aangekom het.

Terwyl die twee Z.A.V.K.-offisiere op pad was na Kaapstad het sekretaris Bourne, na aanleiding van die telegramme wat tussen genls. Smuts en Botha gewissel is, hom oor die toekoms van sommige lede van die Z.A.V.K. begin besin en in die vorm van in 'n aantekening, die vraag gestel of die Unieregering bereid sou wees om die soldyverskil tussen Suid-Afrika en die Britse soldyskale aan te vul. In dié verband het hy die name van maj. G. P. Wallace, en sy mede-offisiere B. H. Turner, G. S. Creed, K. R. van der Spuy en E. C. Emmett en stafsers. Williams (almal Staande Mag) genoteer. Aangaande tydelike lt. J. Clisdal, Z.A.V.K., het die sekretaris aangeteken dat genoemde offisier voor sy toetreding tot die Z.A.V.K. 'n sersant (Z.A.B.S.) was, terwyl lt. H. S. Hewitt vir die duur van die oorlog in SuidAfrika aangestel is (S.M.) en R750 besoldiging per jaar ontvang. Lt. E. F. Driver was 'n soortgelyke geval. Hy het R500 per jaar met 'n vlieënierstoelae ontvang.

Terwyl sekretaris Bourne sy aandag aan die moontlike oorskakeling van Z.A.V.K.-lede gewy het, het die Hoë Kommissaris op 17 Julie 1915 aan genl. Smuts laat weet dat die Britse Minister van Kolonies informasie m.b.t. die aantal vliegtuie en hul afmetings, die aantal beskikbare vlieëniers en ander korpslede begeer wat deel van die aanbod vorm.

Ten einde hierdie vrae te kan beantwoord het sekretaris Bourne op 19 Julie van Walvisbaai gevra of die S.M.-offisiere en stafsers. Williams bereid sal wees om teen die huidige besoldiging by 'n oorsese eskader aan te sluit en of lte. J. Clisdal, E. F. Driver, H. V. Batten, A. R. Earle, W. W. Carey Thomas, John en Power bereid sal wees om teen Imperiale soldy dieselfde te doen. Verder is gevra hoeveel onderoffisiere en manskappe in die Unie ooreenkomstig die Imperiale soldyskale gewerf is en hoeveel manskappe, met insluiting van sers,-maj. L. Higginbotham, teen die bestaande tarief bereid sal wees om by die beoogde eskader aan te sluit.

Ter verduideliking is in dieselfde telegram vermeld dat offisiere en manskappe wat staatsamptenare, of in diens van die Suid-Afrikaanse Spoorweë is, die helfte van hul siviele salaris en geen plaaslike betaling behalwe hul soldy bo en behalwe hul siviele besoldiging sal ontvang nie.

Ofskoon daar op 10 Julie 1915 nog geen antwoord t.o.v. die aanbod van Londen ontvang is nie, telegrafeer die Sekretaris van Verdediging verder:

Go ahead all speed pack everything and prepare move en bloc to Cape Town. Inventory to be made of everything packed and copies sent here early possible date.

Aangaande lt. Weston deel Sekretaris Bourne mee dat hy sy ontslag kan kry, terwyl verlof aan lte. Cripps, Hinshelwood, Wood, Hewitt, Carey-Thomas, Power en Driver toegestaan kan word. Hulle moet ewenwel onmiddellik gereed wees om verdere opdragte te ontvang. Indien hulle nie as vrywilligers wil aansluit nie, kan hulle ontslaan word. 
Van Walvisbaai is die volgende dag berig dat lte. Turner, Hewitt, Hinshelwood en Emmett bereid is om aan te sluit, dat lt. Wood 'n oorplasing benodig en sers.-maj. Williams nie bereid is om aan te sluit nie. Aangaande tydelik lt. Clisdal, lte. Driver, Carey-Thomas en Power (mediese offisier) is meegedeel dat hulle, eweas lt. Earle, sal aansluit. Lt. John was nie gewillig om teen die Imperiale soldy aan te sluit nie. Lt. Creed was met verlof, lt. Cripps met siekverlof. Sers.maj. L. Higginbotham en sers. Trimble was bereid om aan te sluit. Hieruit kan afgelei word dat die kern van die Z.A.V.K. bereid was om in Britse militêre diens te tree, ofskoon almal meer informasie betreffende die Imperiale soldyskale begeer het.

Dieselfde dag is deur die Hoë Kommissaris, met verwysing na genl. Smuts se aanbod van Julie 1915, gerapporteer dat die Imperiale Leërraad die aanbod m.b.t. die Z.A.V.K.-personeel en toerusting aanvaar het en dat voorgestel word dat die offisiere tot die R.F.C. toegevoeg word en die manskappe by die R.F.C. aansluit teen die gewone soldyskale wat vir laasgenoemde korps vasgestel is. By hierdie bedrag kom dan skeidingstoelaes en pensioen.

Tewens was die Britse Leërraad bereid om teen 'n redelike vergoeding dié vliegtuie oor te neem wat eiendom van die Unieregering is. Aangesien vlieëniers dringend benodig is in Frankryk, is versoek dat dié korpslede wat beskikbaar is onmiddellik per skip na Engeland gestuur word. Die ander kan dan, saam met die toerusting, volg wanneer vervoer beskikbaar sal wees.

\section{Van die aanvaarding van die aanbod tot die vertrek na Engeland}

Op 21 Julie 1915 het die Departement van Verdediging na Walvisbaai getelegrafeer dat besonderhede omtrent die soldy en toelaes t.o.v. alle range verkry sal word, terwyl $2 e$ klas lugwerktuigkundiges wat deur maj. Wallace aanbeveel word as le klas. en in hul huidige substantiewe range, na Engeland sal gaan.

Navraag is gedoen in verband met lt. G. S. Creed se adres en aan sers. Trimble is opgedra om na Otavifontein te gaan om daar by sy eenheid aan te sluit, terwyl versoek is dat berig word wanneer die Z.A.V.K. reisvaardig sal wees om na Kaapstad te gaan.

Nog dieselfde dag is die volgende daelikse R.F.C.-soldyskale t.w. vir 'n vlugbevelvoerder R1-70, 'n adjudant R1-70, 'n vlieënier R1-20 (met vlieënierstoelaag van $\mathrm{R} 0-80$ ), 'n sersant R0-60, 'n 1e klas lugwerktuigkundige R0-40 en 2e klas lugwerktuigkundige R0-20 (met vliegtoelae van R0-10 indien van toepassing), na Walvisbaai oorgesein.

Verder sou 'n kaptein R0-30 en 'n luitenant 'n veldtoelae van R0-25 per week ontvang, terwyl spesiale skeidingstoelaes vir personeel wie se vrouens en gesinne in Suid-Afrika woonagtig was ten bedrae van ruim R1-45 tot R3-50 (geen tot 4 kinders), vir korporaals of manskappe ruim R1-45, ongeveer R3-65 vir sersante en ongeveer R1-65 tot R3-85 vir vlugsersante van toepassing sou wees. Vir vrouens en gesinne buite die Unie het laer toelaes gegeld.

In dieselfde telegram is lte. Hinshelwood, Cripps en Wood (almal van die R.N.A.S.) gelas om op 31 Julie 1915 met die posboot van Kaapstad na Engeland te vertrek, terwyl 'n soortgelyke opdrag aan maj. Wallace, tydelike kapts. Turner, Van der Spuy en Creed, lte. Emmett, Clisdal, Hewitt, Driver, Carey-Thomas en Power verstrek is. Die ander moet agterbly om onder leiding van lt. $\mathrm{H}$. V. Batten, alles vir verskeping in gereedheid te bring. Al die Z.A.V.K.-lede wat in Engeland gewerf is, moet met dieselfde kontingent vertrek. Indien lt. Earle bereid sou wees om aan te sluit, moet hy met die reeds genoemde kontingent vertrek terwyl lt. John met lt. H. V. Batten kan volg. 
Op 23 Julie 1915 het die Eerste Minister die Britse Leërraad bedank dat die aanbod aanvaar is en meegedeel dat kennis geneem is van die soldyskale e.d.m. Ter informasie is verder verklaar dat die bedoelde vliegtuie 'n viertal Henri-Farmandubbeldekkers is en dat die res van die toerusting uit 6150 p.k. Canton Unineenjins en ' $n$ groot hoeveelheid onderdele bestaan. Dan is Jaar nog 1 B.E. 2-dubbeldekker en drie 70 p.k. Renault-enjins wat deur die Britse admiraliteit aan die Unieregering geleen is. Die toerusting sluit 'n eskaderoffisiersmotor, 4 ligte werkswinkelmotors en 18 ligte transport motors, almal 6 silinder Studebakers, met 'n groot hoeveelheid onderdele, volledige basis-werkswinkels en alle gereedskap vir 'n eskader in.

Dan volg die volgende lys van offisiere wat op 31 Julie 1915 van Kaapstad na Engeland sal vertrek:

Kapt./tydelike maj. G. P. Wallace, lte./tydelike kapts. K. R. van der Spuy, B. H. Turner en 1t. E. C. Emmett (almal S.M.), lte. Hinshelwood, Cripps en Wood (almal R.N.A.S., toegevoeg tot die Z.A.V.K.) en lt. E. F. Driver; waarnemers lte. J. Clisdal (Z.A.B.S.) en W. W. Carey-Thomas en moontlik It. A. R. Earle, It. S. H. Hewitt (S.M.) en mediese offisier kapt. Power.

Hieraan is toegevoeg dat 1t. Batten en moontlik 1t. John (transportoffisier) so spoedig moontlik met ander eskaderlede sal volg.

Ter verduideliking is t.o.v. die offisiere vermeld dat 6 van hulle S.M.-lede is en dat, m.b.t. hulle en sers.-maj. L. Higginbotham (S.M.), die Unieregering bereid is om die verskil in soldy en toelaes te betaal solank hulle werkprestasies en gedrag tydens hul sekondering in Imperiale diens bevredigend is.

Vier offisiere van bogenoemdes besit tydelike range solank hulle in diens van die Z.A.V.K. is en is toegelaat om dié tot hul aankoms in Engeland te behou. Dan kan, aldus genl. Botha, die War Office verder besluit.

$\mathrm{Al}$ die adjudant-offisiere, korporaals en manskappe sal medies ondersoek en in Imperiale diens geplaas word voordat hulle die Unie verlaat.

Dan volg die verklaring dat die Unieregering alles graag kosteloos sou aangebied het, maar dat die regering erkentlik is dat die Britse regering die finansiële toestand van die Unie ten volle besef. lui:

Van besondere belang is paragraaf 12 , van hierdie skrywe wat soos volg

As regards the employment of the personnel now being sent, Ministers recognise that the needs of the military situation in the European theatre of war must be paramount, but if it is not inconvenient so to arrange, Ministers would be gratified if the personnel could be utilised in some flying unit which could be particularly identified with South Africa.

Ten slotte spreek die Eerste Minister die hoop en die vertroue uit dat dié lede van die Z.A.V.K. wat nou by die R.F.C. aansluit, hulle tot bevrediging van die Britse Leërraad van hul taak sal kwyt.

Op dieselfde dag het die Departement van Verdediging opdrag gegee dat die Z.A.V.K., na aankoms in Kaapstad, gedemobiliseer word en dat alle lede, behalwe dié wat in Engeland aangesluit het, bonusse bereken ooreenkomstig hul substantiewe soldy, moet ontvang en afbetaal moet word. Tewens is meegedeel dat die plan bestaan dat die korps op 25 Augustus 1915 na Engeland sal vertrek.

Vervolgens is 1e klas hoofdekgeriewe vir 31 Julie 1915 vir maj. G. P. Wallace, kapts. K. R. van der Spuy, G. S. Creed, B. H. Turner en lte. Hinshelwood, Cripps, Wood, C. E. Emmett, J. Clisdal, S. H. Hewitt, E. F. Driver en W. W. CareyThomas by die Union Castle-verteenwoordigers op Pretoria bespreek met die vermelding dat die koste deur die Imperiale Leër betaal sal word. 
Kapt. B. H. Turner en die ander offisiere is gelas om op 24 Iulie van Walvisbaai na Kaapstad te vertrek, terwyl maj. Wallace meegedeel het dat die pakwerk op 26 Julie gereed sou wees. Hy het gevra of hy dan met die kontingent na Kaapstad kan gaan en die voorrade onder toesig van 'n K.M.G.-lid kan plaas. Van Pretoria is hierop geantwoord dat hy dadelik kan vertrek en dat die toerusting in Augustus kan volg. Kort daarna is 30 Augustus 1915 as die vertrekdatum vir die personeel onder bevel van 1t. Batten bepaal. Die toerusting sou met dieselfde skip na Engeland gestuur word, terwyl tewens besluit is om kapt. Power nie na Engeland te laat gaan nie aangesien daar vir kontingente onder 150 man geen mediese offisier benodig is nie. Ook is aangeteken dat lt. Earle nie saam met die ander offisiere sal vertrek nie.

Op 30 Julie is dié Z.A.V.K.-offisiere wat medies goedgekeur is en hul bereidwilligheid te kenne gegee het dat hulle na Engeland wil vertrek, meegedeel dat hulle, vir die duur van die oorlog, tydelike Imperiale kommissies in hul huidige substantiewe range vanaf die volgende datums sal ontvang:

Kapt./tydelike maj. G. P. Wallace

5.8.1914.

Lt./tydelike kapt. K. R. van der Spuy

Lt./tydelike kapt.

G. S. Creed

5.8.1914.

Lt./tydelike kapt. B. H. Turner

5.8.1914.

Lt. W. W. Carey-Thomas

23.8.1914.

Lt. S. H. Hewitt

4.1.1915.

Lt. V. H. Batten

26.1.1915.

Lt. J. Clisdal

4.2.1915.

Lt. E. F. Driver

4.3.1915.

Lt. John

20.3.1915.

Tewens is bepaal dat die 4 eersgenoemdes hul huidige tydelike range tot hul aankoms in Engeland sal behou en dat die War Office daarna sal besluit.

Wat, op die dag van vertrek, in Kaapstad aan die gang was, blyk slegs gedeeltelik uit maj. Wallace se telegram van 31 Julie 1915 waarin hy soos volg berig het:

Things are in a terrible mess here with Corps. May 1 remain over till next week with officers. Majority men will enroll for home if I remain. Boat sails one o'clock.

Van Pretoria het die antwoord gekom:

You may remain over till next week.

Nog dieselfde dag is uit Kaapstad gesein:

Maj. Wallace and eleven other officers A.C. sailed per Briton 31 July.

Die volgende telegram, afkomstig van sekretaris Bourne, en gerig aan tydelike maj. Wallace het in Kaapstad aangekom nadat die „Briton” reeds vertrek het:

General Smuts takes opportunity your sailing to England to congratulate you and corps on your work in South West Africa to wish you bon voyage and to express confidence that you will all acquit yourselves with credit to South Africa.

Maj. Wallace, lte. van der Spuy, Creed, Turner, Emmett, Hinshelwood, Cripps, Wood, Driver, Clisadl, Carey-Thomas en Hewitt was op pad na Engeland. 


\section{Personeel-aangeleenthede}

Terwyl genl. Botha die Britse regering op 23 Julie 1915 versoek het dat daar op die een of ander wyse 'n band tussen die voormalige Z.A.V.K. en SuidAfrika gelê word, het die Hoë Kommissaris op 6 Augustus 1915 aan die Departement van Verdediging getelegrafeer dat hy van die Minister van Kolonies verneem het dat, ofskoon daar geen moeilikhede ondervind word om die geledere van die R.F.C. te vul nie, die Britse Leërraad bereid sal wees om die dienste van SuidAfrikaners te aanvaar om die oprigting van 'n Suid-Afrikaanse eenheid te voltooi.

Volgens die Britse Leërraad was daar voldoende offisiere en manskappe in die Unie om die voorgestelde eenheid tot eskader-sterkte, nl. 28 offisiere, 20 onderoffisiere en 161 lugwerktuigkundiges, m.a.w. 'n totaal van 209, op te voer. Hierby sou, imdien moontlik, nog 'n ekstra viug van 40 offisiere en manskappe bygevoeg kan word om as 'n reserwe-eenheid te dien.

Genl. Smuts wat hierdie skrywe, wat op 25 Augustus 1915 deur die Britse Minister van Kolonies aan die goewerneur-generaal gestuur is, beantwoord het, het op 1 September 1915 geantwoord dat feitlik elke offisier wat 'n praktiese lugvaartopleiding ontvang het, reeds na Engeland gegaan het of binnekort met die Z.A.V.K. soontoe sal gaan. M.b.t. gekwalifiseerde nie-offisiere het hy berig dat 'n groot deel van hulle wat in Suidwes in die Z.A.V.K. gedien het, vrywillig vir diens in Europa aangesluit het en in September sal vertrek. Volledige besonderhede i.v.m. laasgenoemde groep is weliswaar nog nie beskikbaar nie, maar die groottotaal sal - met insluiting van hulle wat spesiaal in Engeland gewerf is - nie meer as 120 bedra nie.

Ofskoon Suid-Afrika dus in 'n moeilike posisie verkeer het, het genl. Smuts belowe dat die Unieregering alles in sy vermoë sal doen om meer personeel te werf sodat die Suid-Afrikaanse eenheid oor die verlangde sterkte, met dié vary 'n bykomstige vlug, sal beskik. Daar moet ewenwel duidelik verstaan word dat toekomstige rekrute nie oor vorige lugvaart-ondervinding hoef te beskik nie, aldus genl. Smuts. Die keuring sal noukeurig geskied sodat die toekomstige vrywilligers na 'n kort opleiding in Engeland gebruik kan word.

Aan die slot van sy skrywe vra genl. Smuts ıan die goewerneur-generaai om die mening van die Leërraad in te wen en of, soos gereël, die adjudant van die eenheid (lt. H. V. Batten) in die Unie kan bly.

Die Leërraad het vervolgens begin om voorwaardes t.o.v. die opneming van kandidate vir die R.F.C. te oorweeg, maar terselfdertyd die goewerneurgeneraal versoek om navraag m.b.t. geskikte kandidate te doen.

Voordat ' $\mathrm{n}$ beslissing in Londen geneem is, is berig op Pretoria ontvang dat kapt. Batten, nog 'n offisier, 2 onderoffisiere, 4 stafsersante en 137 manskappe op 19 September 1915 met die „Llandovey Castle” na Engeland sal afreis. Kort voor hierdie datum is kapt, Batten meegedeel dat hy in Kaapstad sal bly en da: die Direkteur van Werwing die behoeftes van die Z.A.V.K. met hom sal bespreek.

Terwyl werwingsaangeleenthede dus in die Unie onder oë geneem is, het maj. Wallace op 18 September 1915 'n skrywe aan genl. Smuts gerig waarin hy verklaar het dat die adjunk-direkteur Militêre Lugvaart, kol. Marindin, tevrede is met die Suid-Afrikaanse offisiere en gewillig is dat die eenheid soveel moontlik uitbrei.

Maj. Wallace het verder, t.o.v. die personeelposisie, meegedeel dat daar 'n veertigtal werktuigkundiges in die Unie aangeneem is om die sterkte van die eskader in ooreenstemming met die R.F.C.-voorskrifte te bring. 
Sodra die werktuigkundiges in Engeland aangekom het, sal die hele groep na Netheravon vertrek, waar 'n opleidingsinrigting m.b.t. meganiese kennis en praktiese vliegervaring opgerig kan word.

Indien daar meer werktuigkundiges in Suid-Afrika verkry kan word, kan die eskader uitgebrei en 'n vleuel gevorm word, want - so gaan maj. Wallace verder:

... each expansion adds a better chance of its earning distinction for South Africa in Flanders, and this merely by the obtaining of recruit mechanics at no expense to South Africa.

Interessant is sy slotopmerking m.b.t. genl. Smuts se telegram van 31 Julie 1915 wat klaarblyklik nog op die een of ander wyse in sy besit gekom het en waaromtrent hy soos volg skrywe:

... the difficulties of operating with an Air Service in South West Africa can probably only be appreciated by those engaged in it. I have no hesitation in saying that is was only by the thorough keenness shown by all ranks, the close co-operation between officers and men, and the splendid spirit of the mechanics, especially those engaged in South Africa who, it must be remembered, had had no previous knowledge of the working of an Air Squadron, that enabled the Corps to be of use which 1 believe it was and to assist the Commander-in-Chief at the final surrender at Kilo 500.

Op 20 September 1915 het die Hoë Kommissaris aan genl. Smuts meegedeel dat, m.b.t. die toelatingsvereistes t.o.v. die R.F.C., die volgende geld:

a Kandidate met domisilie in die dominiums wat 'n kommissie in die R.F.C begeer. moet oor 'n kommissie in die dominiale magte beskik, oorsese diens aanvaar het met genoemde magte en oor 'n aanbeveling beskik dat hulle geskik vir die R.F.C. is.

b Hulle wat, as gevolg van hul geskiktheid vir diens in die R.F.C., oor 'n spesiale kommissie beskik, moet 'n kommissie as 2e luitenant (infanterie) ontvang.

c Offisiere sal kostelose vervoer na Engeland ontvang en moet na aankoms 'n lugvaartkursus volg.

d Indien hulle as vlieëniers slaag, sal hulle by die R.F.C. geplaas word. Slaag hulle nie dan moet hulle by die kontingente van hul onderskeie dominiums aansluit.

e Kandidate moet tussen 18 en 30 jaar oud wees, oor normale gesigsvermoë beskik, geen bril dra nie en die mediese raad bevredig dat hulle nie aan doofheid of oorsiektes ly nie en dat hul asemhalingsorgane en senuweestelsel normaal is. Tewens moet verseker word dat kandidate geskik is vir algemene diens.

Op 20 September 1915 het die goewerneur-generaal, met die oog op personeel-behoeftes vir die beplande Suid-Afrikaanse R.F.C.-eskader, op versoek van die $\boldsymbol{W}$ ar Office die volgende gegewens aan die Unieregering gestuur:

a Oorlogsterkte-tabelle.

b 'n Oorsig van die provisionele verspreiding van korporaals en lugwerktuigkundiges in 'n eskader.

c Besonderhede aangaande soldy en toelaes m.b.t. R.F.C.-offisiere, -onderoffisiere en manskappe.

In hierdie gegewens is die volgende besonderhede verstrek: 


\section{A SQUADRON - ROYAL FLYING CORPS \\ (12 Aeroplanes)}

\section{WAR EST ABLISHMENT}

\begin{tabular}{|c|c|c|c|c|c|c|}
\hline Detail & $\stackrel{\substack{5 \\
0}}{0}$ & 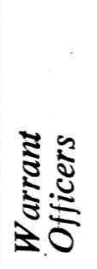 & 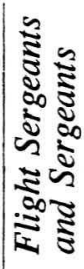 & 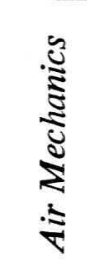 & تี & Remarks \\
\hline $\begin{array}{l}\text { Headquarters } \\
\text { (excluding attached) } \\
\text { Headquarters } \\
\text { (attached) ................. } \\
\text { Two Flights .................... } \\
\text { One Wireless Flight }\end{array}$ & $\begin{array}{l}2 \\
7(a) \\
12 \\
7\end{array}$ & $\begin{array}{l}2 \\
- \\
-\end{array}$ & $\begin{array}{c}2 \\
\frac{10}{6}\end{array}$ & $\begin{array}{r}28 \\
7 \\
58 \\
68\end{array}$ & $\begin{array}{l}34 \\
14 \\
80 \\
81\end{array}$ & \multirow[t]{2}{*}{$\begin{array}{l}\text { (a) } 7 \text { officers } \\
\text { attached as } \\
\text { observers. }\end{array}$} \\
\hline $\begin{array}{l}\text { Total Squadron } \\
\text { (excluding attached) } \\
\text { Total Squadron } \\
\text { (including attached) }\end{array}$ & $\begin{array}{l}21 \\
28\end{array}$ & $\begin{array}{l}2 \\
2\end{array}$ & $\begin{array}{l}18 \\
18\end{array}$ & $\begin{array}{l}154 \\
161\end{array}$ & $\begin{array}{l}195 \\
209\end{array}$ & \\
\hline
\end{tabular}

(ii) Transport

\begin{tabular}{|c|c|c|c|c|}
\hline Detail & $\begin{array}{c}\text { Head- } \\
\text { quarters' } \\
\text { vehicles }\end{array}$ & $\begin{array}{c}\text { Two } \\
\text { Flights' } \\
\text { vehicles }\end{array}$ & $\begin{array}{c}\text { Wireless } \\
\text { Flight } \\
\text { vehicles }\end{array}$ & $\begin{array}{c}\text { Total } \\
\text { vehicles }\end{array}$ \\
\hline Lorry Wireless, Shop ........ & $\overline{-}$ & - & $\bar{I}$ & $\bar{I}$ \\
\hline Motor Cars ............... & 1 & - & - & 1 \\
\hline Light tenders ..................... & 1 & 4 & 4 & 9 \\
\hline Heavy tenders & 3 & 8 & 4 & 15 \\
\hline Repair lorries & 1 & 2 & 1 & 4 \\
\hline Motor bicycles & 2 & 4 & $7(\mathrm{~g})$ & 13 \\
\hline . & - & 6 & 2 & 8 \\
\hline Side cars & - & 2 & 6 & 8 \\
\hline Total & 8 & 26 & 25 & 59 \\
\hline
\end{tabular}

(g) 2 fitted with side-cars.

NOTE: No drivers of mechanical transport are shown, except for two heavy tenders for baggage and supplies, as all air mechanics will be trained to drive the vehicles. 
(i) Personnel

\begin{tabular}{|c|c|c|c|c|c|c|}
\hline HFADOUARTERS. & 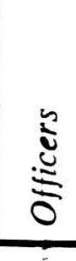 & 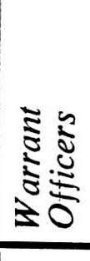 & 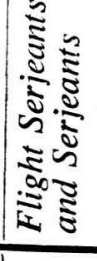 & 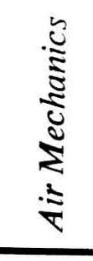 & $\begin{array}{l}\overrightarrow{0} \\
0 \\
\end{array}$ & Remarks \\
\hline 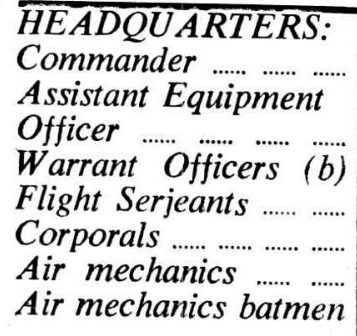 & $\begin{array}{l}1 \\
1 \\
- \\
- \\
- \\
-\end{array}$ & $\begin{array}{l}- \\
- \\
2 \\
- \\
- \\
-\end{array}$ & $\begin{array}{l}- \\
- \\
\frac{2}{-} \\
-\end{array}$ & $\begin{array}{l}- \\
- \\
- \\
1 \\
25 \\
2\end{array}$ & $\begin{array}{r}1 \\
1 \\
2 \\
2 \\
1 \\
25 \\
2\end{array}$ & \multirow{6}{*}{$\begin{array}{l}\text { (b) } 1 \text { serjeant-major, } \\
1 \text { technical ser- } \\
\text { jeant-major. } \\
\text { (c) Batmen for } \\
\text { observers. }\end{array}$} \\
\hline $\begin{array}{l}\text { Total } \\
\text { ATT ACHED: } \\
\text { Observers } \\
\text { Drivers A.S.C. } \\
\text { (mechanical } \\
\quad \\
\text { transport) }\end{array}$ & $\begin{array}{r}2 \\
7 \\
-\end{array}$ & $\begin{array}{r}2 \\
- \\
-\end{array}$ & $\begin{array}{r}2 \\
- \\
-\end{array}$ & $\begin{array}{c}28 \\
3(c) \\
4\end{array}$ & $\begin{array}{r}34 \\
10 \\
4\end{array}$ & \\
\hline $\begin{array}{l}\text { Total Headquarters } \\
\text { (including attached) } \\
\text { TWO FLIGHTS } \\
\text { EACH: } \\
\text { Flight Commander } \\
\text { Flying Officers } \\
\text { Flight Serjeants ........... } \\
\text { and Serjeants } \\
\text { Corporals } \\
\text { Air mechanics ................ } \\
\text { Air mechanics batmen }\end{array}$ & $\bar{z}$ & $\begin{array}{l}- \\
-\end{array}$ & $\begin{array}{l}- \\
- \\
- \\
-\end{array}$ & $\begin{array}{r}4 \\
19 \\
6\end{array}$ & $\begin{array}{r}1 \\
5 \\
\\
5 \\
4 \\
19 \\
6\end{array}$ & \\
\hline 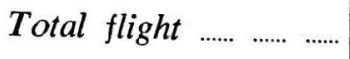 & 6 & - & 5 & 29 & 40 & \\
\hline Total 2 Flights ............ & 12 & 二 & 10 & 58 & 80 & \\
\hline 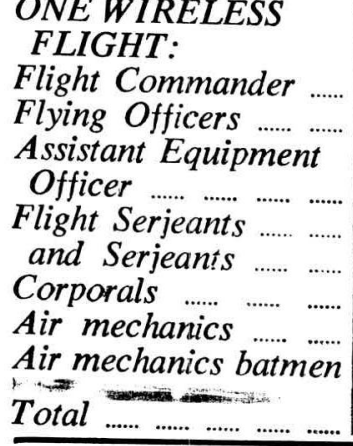 & $\begin{array}{l}1 \\
- \\
- \\
7\end{array}$ & $\begin{array}{l}- \\
- \\
- \\
-\end{array}$ & $\begin{array}{l}- \\
- \\
6(d) \\
- \\
- \\
6\end{array}$ & $\begin{array}{l}- \\
- \\
- \\
\overline{7}(e) \\
55(f) \\
6 \\
68\end{array}$ & $\begin{array}{r}1 \\
5 \\
1 \\
6 \\
7 \\
55 \\
6 \\
81\end{array}$ & \\
\hline
\end{tabular}




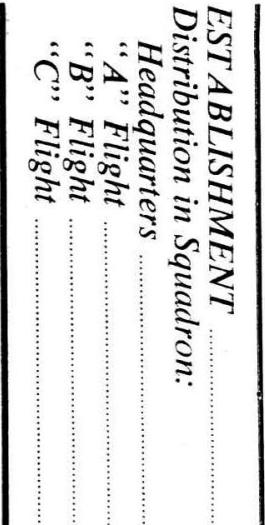

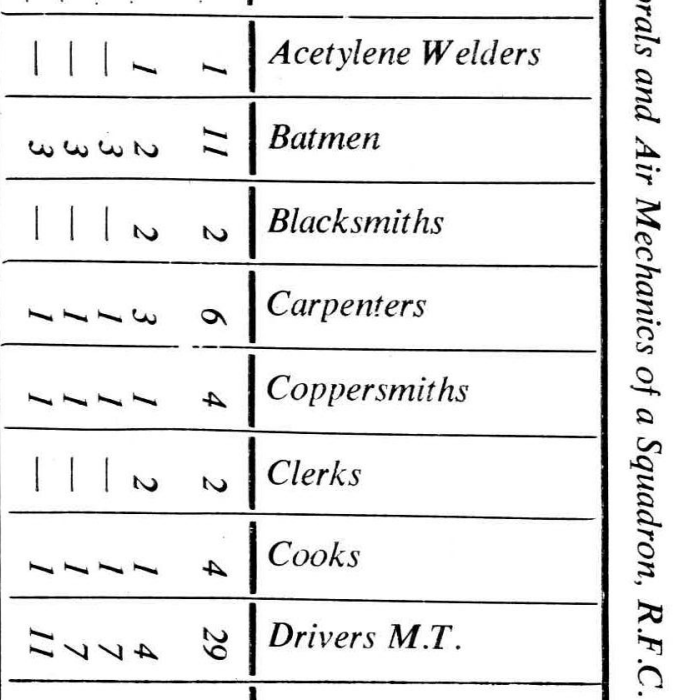




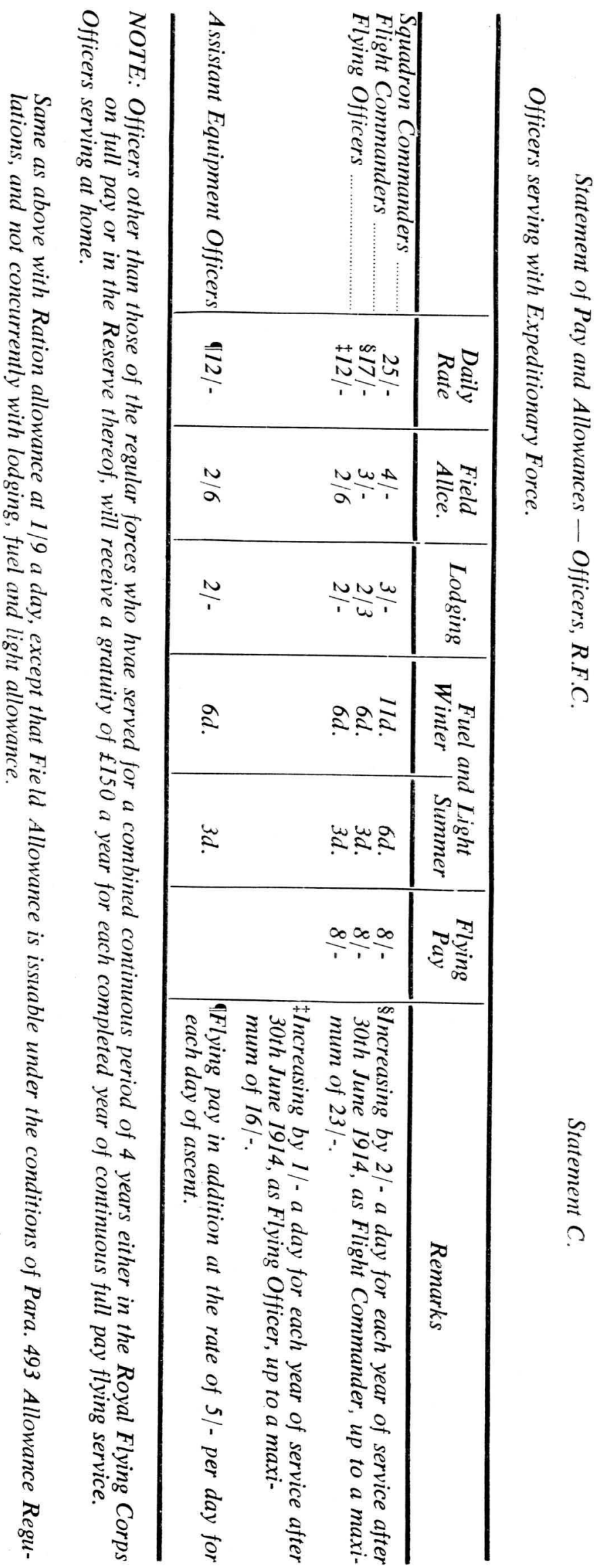




\section{Statement $C$}

\section{Statement of Pay - W.O.'s, N.C.O.'s and Men}

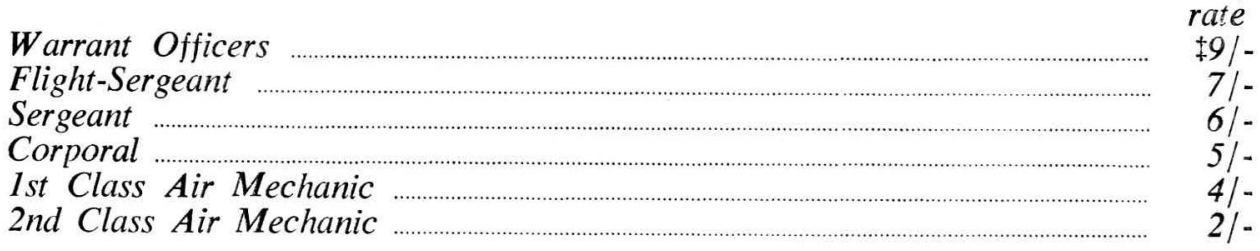

Field allowance; in addition $1 /$-.

W.O.'s, N.C.O.'s and men who are 1st class pilots receive in addition 4/- a day flying pay. If 2 nd class pilots $2 /-$ a day.

Op 22 September 1915 is kapt. H. V. Batten van Kaapstad na Pretoria ontbied om besonderhede m.b.t. die eenheid na te gaan en om vas te stel watter geskooldes in die hoofstad gevind kan word, terwyl genl. Smuts op 2 Oktober deur Londen versoek is om werktuigkundiges te laat werf op voorwaarde dat hulle in die vaktoets, soos deur die vroeëre Z.A.V.K. gebruik is, slaag. Tewens kon, ooreenkomstig die voorwaardes wat reeds na Pretoria gestuur was, kandidaat-offisiere vir die R.F.C. aangeneem word.

$\mathrm{Na}$ aanleiding van hierdie versoeke het genl. Smuts op 3 Oktober 1915 gevra hoeveel offisiere aangeneem moet word en verklaar dat hy dit nie oorweeg om kandidate vir algemene diens in die R.F.C. te stuur nie, maar wel genoeg om die Suid-Afrikaanse R.F.C.-eskader op volle sterkte te bring.

'n Paar dae later het die Sekretaris van Verdediging aan die Kamer van Mynwese gevra om te help om vakmanne to probeer vind om die Z.A.V.K. tot 'n volledige eenheid van die R.F.C. te kan uitbou.

Op dié tydstip was daar nog 1 ingenieur, 7 offisiere-waarnemers, 1 radiooperateur, 5 vlieëniers en 14 ondergeskiktes kort. Genl. Smuts het op 8 Oktober 1915 telegrafies belowe om laasgenoemde 14 te probeer vind en vra of Londen 14 werktuigkundiges of 95 vakmanne begeer om die eskader op sterkte te bring.

Hierop is geantwoord dat al die personeel, soos deur genl. Smuts genoem,

en nog 24 telegrafiste benodig is. Hulle sal as radio-operateurs opgelei word.

Hierdie informasie is op 11 Oktober 1915 aan kapt. Batten, p.a. Drilsaal, Kaapstad, gestuur, terwyl reeds vroeër 'n persverklaring deur die Departement van Verdediging vrygestel is, waarin melding gemaak is dat aansoeke m.b.t. vakatures in die Suid-Afrikaanse R.F.C.-eskader ingewag word van kokke, elektrisiëns, werktuigkundiges, instrumentmakers, kopersmede, seilmakers, passers, draaiers e.a. ambagsmanne.

In die aankondiging is die volgende soldy vermeld: Adjudant-offisiere R0-90, vlugsersante - R0-70, sersante - R0-60, korporaals - R0-50, 1e klas lugwerktuigkundiges - R0-40 en 2e klas lugwerktuigkundiges R0-20 per dag.

Applikante moes hulle op 5 Oktober by kapt. Batten, adjudant Z.A.V.K., aan die Johannesburgse Drilsaal aanmeld of op 6 Oktober by die werwingskantoor, Stadhuis, Pretoria, verskyn terwyl kapt. Batten op en na 11 Oktober 1915 gegadigdes in die werwingskantoor, Stadhuis, Kaapstad, te woord sou staan ${ }^{4}$. 
Op 29 Oktober 1915 het genl. Botha aan die goewerneur-generaal 'n skedule van name van Z.A.V.K.-offisiere, toegevoeg tot die R.F.C., met datums van senioriteit en range gestuur en tewens berig dat 2lt. Earle op 18 September j.l. met die „Llandovery Castle” na Engeland vertrek het, dat kapt. Batten werwingswerk in Kaapstad verrig en met die volgende groep vrywilligers sal vertrek ${ }^{5}$.

Hierdie groep het op 8 November 1915 vertrek en onder hulle was die

volgende offisiere: V. M. C. de B. Sarigny, Seal, J. D. Francis, P. L. Lindup, T. Dixon, H. V. Batten, Meintjes, G. A. Limouzin en F. W. Honnet'.

Teen die einde van 1915 was die Suid-Afrikaanse eskader, wat in Oktober 1915 by die R.F.C. ingelyf was, gereed vir aktiewe diens'.

4 Klagtes. Die S.A.-eskader deel van die R.F.C.

Soos bekend het die Suid-Afrikaanse eskader. nadat die opleiding in Engeland voltooi was, na Duits Oos-Afrika vertrek

Terwyl die personeellede op pad soontoe was, het eskader-bevelvoerder maj. Wallace na aanleiding van 'n skrywe van 8 Januarie 1915 van sers.-maj. J. Pearson, op 22 Januarie 1916 in 'n skrywe oor klagtes i.v.m. die betaling van eskaderlede uitgewei.

In sy skrywe het die sers.-maj. verklaar dat, na die reorganisasie van die Z.A.V.K., in Kaapstad, die korpslede wat aangesluit het, aanmerklik laer besoldig is as vroeër die geval was. $\mathrm{Na}$ aankoms in Engeland is toetse afgelê en kursusse gevolg en is die eskader deur kol. Charlton, R.F.C., te Farnborough gelukgewens met sy puik drilvertoning. Na 3 maande se opleiding te Netheravon is die eskader spesiaal uitgesoek vir diens in Duits Oos-Afrika. Goeie behandeling is weliswaar met waardering ontvang maar daar is klagtes, t.w. die verskil in soldy t.o.v. gelykgekwalifiseerde R.F.C.- en ander Imperiale eenhede m.b.t. motorbestuurders. Dan verkeer die eskaderlede onder die indruk dat, indien hul bekwaamhede dit sou regverdig, hulle as 1e klas werktuigkundiges $40 \mathrm{c}$ per dag i.p.v. $20 \mathrm{c}$ as $2 \mathrm{e}$ klas werktuigkundiges sou ontvang. Volgens sers.-maj. Pearson regverdig die sterkte van die eskader 'n sekere persentasie 1e klas werktuigkundiges terwyl elke eskaderlid volgens hom goed gekwalifiseer is. Hy voeg hieraan toe dat die eskaderlede aangesluit het om hul land te help en tenminste verwag dat die laagste skale betaal sal word.

Aan die slot van die skrywe verklaar die briefskrywer dat die ontevredenheid onmiddellik sal verdwyn indien 'n koloniale toelae toegestaan word waardeur die betaling gelyk sal staan aan die van ander meganiese korpse in Suid-Afrika.

Sers.-maj. Pearson eindig sy skrywe met die volgende pleidooi:

We are South Africans serving in Africa, and should surely be treated, at any rate as well, as other South Africans: and not kept at a much lower rate of pay through having shown our greater keenness and patriotism.

In sy begeleidende brief het maj. Wallace die aangehaalde pleidooi ondersteun en gevra of die Unieregering die beswaar kan ophef deur 'n spesiale toelae beskikbaar te stel aangesien daar van Britse kant geen koloniale toelae verstrek word nie.

Hoofklerk A. E. Basden se kommentaar van 5 Februarie 1916 is, in meer as een opsig, belangrik wanneer hy skrywe: officers and men are interchangeable as between the S.A. and any 
other squadrons. The squadron is not the S.A. Aviation Corps but R.F.C. with merely special designation, preserving identity. All members of the squadron are not recruited in S.A.

Basden se uitspraak was gebaseer op die inhoud van 'n belangrike ver. troulike skrywe wat gen.-maj. sir David Henderson, K.C.B., D.S.O., van die Military Aeronautics Directorate, Londen, in November 1915 aan genl. Smuts gestuur het ${ }^{9}$.

Aanleiding tot hierdie skrywe was vermoedelik die vraag wat aan genl.maj. sir David Henderson gestel is waar die rekords van die Suid-Afrikaanse eskader bewaar moet word. Op hierdie vraag het die generaal tydens 'n onderhoud op 6 November 1915 geantwoord dat hy wel bereid is dat die identiteit van die eenheid, soos dit in die benaming tot uiting kom, behoue bly. Hy was ewenwel nie bereid om toestemming te verleen om die eskader uitsluitend vir Suid-Afrika voor te behou nie. Enige R.F.C.-lid kon, volgens sy mening, na die Suid-Afrikaanse eskader oorgeplaas word en m.b.t. die eskader se rekords het hy voorgestel dat hulle aan die R.F.C. se rekordoffisier oorhandig word.

Aan genl. Smuts het die generaal geskrywe dat daar 'n mate van misverstand aangaande die organisasie van die S.A.-eskader bestaan. Ingaande op die ontstaan van die eenheid het genl.-maj. Henderson verklaar dat die eskader aangebied en aanvaar is voordat daar oor die Suid-Afrikaanse kontingent besluit is. $\mathrm{U}$ het, aldus genl.-maj. Henderson aan genl. Smuts, gevra dat dit soveel moontlik 'n Suid-Afrikaanse eenheid bly en ons het dit aanvaar en gelyktydig die wenk gegee dat die offisiere tot die R.F.C. toegevoeg word en die ander lede tot die R.F.C. toetree. Die rede hiervoor is dat die R.F.C. tegnies sowel as militêr is. Die manskappe is uit verskillende vakrigtings saamgestel en in 'n bepaalde verhouding in die eenheid opgeneem. Kom daar 'n tekort dan kan dit dalk meebring dat die eskader lamgelê word. Bygevolg, so gaan die generaal verder, is dit nodig dat hy aanvul vanwaar hy die personeel kan kry en dié personeel wat nog nie op die vereiste oorlogspeil is nie, na opleidingsinrigtings terugstuur.

Dit is beter dat die Suid-Afrikaanse eskader 'n integrale eenheid van die R.F.C. word, aldus die briefskrywer wat dan verder skrywe:

It will be called the South African Squadron, and in every way it will be kept South African; but unless we have discretion with regard to individuals, its efficiency is bound to suffer. If, under these conditions, you will give me a free hand, I will undertake that you shall be proud of your squadron.

Genl.-maj. sir David Henderson skrywe dan verder:

$I$ should like to take this opportunity of telling you how admirably your flying officers served us in France in the early stages of the campaign: I have heard also that they did fine work, under great difficulties, in South West Africa. And may I congratulate you on your share in that enterprise and on the wonderful work you have done for South Africa since we parted in Pretoria years ago.

Op 2 Desember 1915 het sekretaris Bourne aan genl.-maj. sir David Henderson getelegrafeer:

There is not the least objection on our part to the South African Squadron becoming an integral unit of the Royal Flying Corps. Our object is to give you the best possible assistance in the way you want $i t^{10}$. 
Teruggaande na die klagtes van maj. G. P. Wallace en sers.-maj. Pearson kan opgemerk word dat die personeel van die Suid-Afrikaanse eskader op 11 Februarie 1916 tevrede gestel is. Op dié dag is deur die Sekretaris van Verdediging die volgende opdrag na Nairobi gestuur:

Please inform S.A. Squadron R.F.C. that all Officers, N.C.O.s and

Other Ranks come to same rates of pay and allowances as Units of Union Part African Forces from date of arrival at Kilindini.

\section{Die lot wat die aankope getref het}

Soos reeds vermeld is, het die Britse regering kort na die beëindiging van die veldtog in Suidwes aangebied om die Z.A.V.K.-toerusting teen 'n redelike prys oor te neem.

Volgens die verslag van die Kontroleur en Ouditeur-generaal oor die finansiële jaar 1915-1916 het 6 vliegtuie, 22 motors, 7 motorfietse en groot hoeveelhede onderdele en toebehore ruim R52 623 gekos".

In Desember 1915 en in Julie 1916 is navraag m.b.t. die inventarislyste van die verkoopte toerusting gedoen, maar op dié tydstip was nog geen gegewens van die Hoë Kommissaris ontvang nie. Tydens die volgende finansiële jaar het aankope deur die Z.A.V.K. ten bedrae van ruim R1 477 weer onder die aandag van die Kontroleur en Ouditeur-generaal gekom en in die verslag oor 1916-1917 is o.m. in bogenoemde verband verklaar dat die verkoop van die betrokke toerusting nie voldoende verklaar kan word nie ${ }^{\prime 2}$.

Hoeveel toerusting die Britse regering oorgeneem het, is onbekend maar op 16 November 1915 het maj. Wallace van Netheravon aan die Hoë Kommissaris in Londen geskrywe dat hy verneem het dat die waardevolste gedeelte van die materiaal in die opelug op Farnborough lê en dat onder dié omstandighede op 'n waardevermindering teen R100 per dag gereken kan word. Die kantoor van die Hoë Kommissaris het op 22 November 1915 aan tydelike maj. Wallace laat verstaan dat hulle nie weet watter toerusting na Engeland verskeep is en met watter

skepe dit vervoer is nie.

Wel weet hulle dat alles ter beskikking van die Leërraad gestel is, maar daarna is niks meer verneem nie.

Op 6 Desember 1915 het maj. Wallace van Netheravon geskrywe dat die vliegtuigmateriaal nou van Farnborough verwyder word en dat die voertuie deur hom en 'n inspekteur nagegaan is. Hulle het tot die konklusie gekom dat die waarde van die voertuie met ongeveer R50 per stuk verminder het. is en vervolg:

Aangaande die vliegtuie het hy verneem dat hulle na Londen oorgebring

1 hear (unofficially) that one machine was found so rusted up as to be useless - here is $£ 1000$ gone.

Wat verder van die toerusting van die voormalige Z.A.V.K. geword het, blyk nie uit die inhoud van die geraadpleegde dokumente nie. Wel het, as gevolg van briefwisseling wat uit maj. Wallace se mededelinge voortgevloei het, die volgende gegewens aan die lig gekom: Die grootste hoeveelheid Z.A.V.K.-toerusting is op 2 September 1915 met die "Cluny Castle" na Engeland gestuur en die res het op 18 September 1915 met die „Llandovery Castle” gevolg. Met eersgenoemde skip is 6 vliegtuie, 21 motorvoertuie, 5 vliegtuig-sleepwaens, 5 motorfietse, 3 syspanne en 301 pakke met onderdele verskeep. Deur maj. Wallace is die inventarislyste nooit aan die Hoë Kommissaris oorhandig nie. Eersgenoemde is 
van agtelosigheid beskuldig omdat hy die opdrag wat aan hom verstrek is nie nagekom het nie. Tot 25 September 1916 het die Kontroleur en Ouditeur-generaal tevergeefs vir verduideliking by die Departement van Verdediging aangeklop. Op 2 November 1916 het die Sekretaris van Verdediging 'n aantal verklarings, t.w. van maj. G. P. Wallace (Hoofkwartier R.F.C., Oos-Afrika, 15.9.1916), kapt. B. H. Turner (Morogoro, 15.9.1916), kapt. A. R. Earle (H.K., R.F.C., Oos-Afrika, 21.9.1916), 2lt. F. C. Buck (R.F.C., Wynberg) en kapt. H. V. Batten (Kilwa, 18.10.1916) aan die Kontroleur en Ouditeur-generaal gestuur. Maj. Wallace het erken dat hy opdrag ontvang het om alles te verpak en op sy beurt 1t. Turner met dic taak belas het. Alles is verpak en nadat 'n aantal offisiere na Kaapstad is, was lt. Batten in bevel van die Z.A.V.K. Na 31 Julie 1915 sou, aldus maj. Wallace, die Departement van Verdediging beheer oor die Z.A.V.K.-aangeleenthede oorgeneem het.

Lt. Turner het verklaar dat die inventarislys deur hom op Walvisbaai aan die dienskamer oc:handig is. Lt. Earle het stukkende kaste en voorrade in Kaapstad sien lê, na die vertrek van lt. Batten alles bymekaar laat soek en alles weer verpak en lt. Buck in bevel geplaas. Volgens hom is 'n inventarislys na die dienskamer van die Kasteel geneem. Ongeveer soortgelyk is die verklaring wat deur It. Batten afgelê is, maar op 20 Junie 1917 is van die Kasteel berig dat daar geen Z.A.V.K.-rekords aangetref is nie.

Hoofklerk Basden het op 21 Junie 1917 die opdrag insake die opstel van 'n inventaris gevind en na aanleiding hiervan het sekretaris Bourne op 23 Junie 1917 geantwoord:

I am very glad to hear this. The matter of these aviation stores is one which has been causing me a good deal of anxiety, as it lays the Dept. open to very serious criticism.

Terwyl die Sekretaris van Verdediging tot hierdie gevolgtrekking gekom het, was daar 'n deurtastende ondersoek deur die Departement van Verdediging aan die gang waaruit o.m. blyk dat, nadat vrag met die „Cluny Castle” en die „Llandovery Castle” verskeep is, daar op 8 November 1915 nog een motor en vier kaste met leë bomme na Engeland gestuur is. Op grond van navrae m.b.t. die versending van die materiaal is tot die gevolgtrekking gekom dat maj. Wallace die opdrag om 'n inventaris op te stel, gerepudieer het. Verder was, aldus die verslag, 1t. Earle ook gedeeltelik te blameer.

Verder is aanbeveel dat vasgestel moet word watter voorrade deur die War Office ontvang is ien einde 'n afrekening te kan opstel en betaling te ontvang. Omstreeks Julie 1917 het brig.-genl. J. J. Collyer, C.B., C.M.G., die aangeleentheid in Londen bespreek, terwyl in Oktober 1917 - nadat uitdruklik verklaar is dat die tydsverloop dit onmoontlik gemaak het om elke item afsonderlik te waardeer maar met inagneming van die toestand waarin die materiaal ten tye van ontvangs verkeer het - bssluit is dat die Unieregering 'n bedrag van R20 400 sal ontvang. Op 21 Januarie 1918 het die Unieregering besluit om die aanbod te aanvaar en op 26 Februarie 1918 het die Hoë Kommissaris aan die Sekretaris van Verdediging meegedeel dat die genoemde bedrag van die War Office ontvang is.

\section{Verdere besonderhede}

Met die lot van die vliegtuie van die Z.A.V.K. eindig die belangrikste gegewens, afkomstig uit 'n drietal lêers wat m.b.t. die Suid-Afrikaanse eskader (R.F.C.) geraadpleeg is.

Verdere besonderhede aan hierdie lêers ontleen, is die volgende: 
eerw. A. Moultrie, Matatiele, Oos-Griekwaland, tuisgegaan en het omstreeks 18 Februarie oor Durban na Oos-Afrika teruggekeer.

In April 1916 is daar meer aansoeke van sweisers, smede, instrumentmakers, elektrisiëns en seilmakers vir die Suid-Afrikaanse eskader (R.F.C.) in Oos-Afrika gevra.

Suksesvolle kandidate sou as 2e klas lugwerktuigkundiges teen 'n daelikse soldy van R0-30 en R0-70 ekstra vergoeding, met hierby 'n skeidingstoelae soos vir Imperiale eenhede vasgestel was, ontvang en moes vir die duur van die oorlog en 6 maande daarna aansluit.

Aan die begin van November 1916 het kapt. A. M. Miller, D.S.O., oorspronklik afkomstig van Swaziland, in die Unie aangekom om personeel vir die R.F.C. te werf, terwyl in dieselfde maand onder die opskrif „Royal Flying Corps. Recruits wanted for S.A. squadron” die aandag van die publiek gevestig is op die volgende personeel wat benodig is: 30 passers, 10 skrynwerkers, 5 seilmakers, 4 draaiers en 4 instrumentmakers ${ }^{13}$.

Tydens sy eerste werwingsveldtog, in 1916-1917, het maj. Miller ongeveer 400 rekrute gewerf en was daar reeds meer as 500 Suid-Afrikaners in die R.F.C., terwyl hy tydens sy tweede besoek aan die Unie beoog het om 1000 rekrute te werf'.

Op 29 Junie 1917 het, in korrespondensie tussen die War Office en die Departement van Kolonies, die besoldiging van personeel van 26 Eskader R.F.C. ter sprake gekom. Hieruit blyk dat die Departement van Kolonies die Unieregering beweeg het dat genoemde personeel, na aankoms in Oos-Afrika, ooreenkomstig die Suid-Afrikaanse skale besoldig sal word, m.a.w. dat laasgenoemde regering die verskil tussen die Imperiale skale en die Suid-Afrikaanse skale betaal.

In dieselfde skrywe is ook melding gemaak dat die status van die eskader kort gelede deur brig.-genl. J. J. Collyer, C.B., C.M.G. (namens genl. J. C. Smuts) en die War Office bespreek en dat soos volg besluit is:

a Die eskader sal as 'n integrale deel van die R.F.C., en nie as 'n eenheid van Suid-Afrika se Imperiale Dienskontingente nie, beskou word.

b Dat op grond hiervan die personeel wat vir algemene diens aangesluit hetsy ten tye van die eenheid se vertrek uit Oos-Afrika vir enige deel van die wêreld beskikbaar sal wees en weer ooreenkomstig Imperiale skale besoldiging sal ontvang.

c Die oorblywende personeel, m.a.w. die gedeelte wat uitsluitend vir diens in Oos-Afrika aangesluit het, sal ten tye van die vertrek van die eskader uit Oos-Afrika ophou om hiertoe te behoort, maar toegelaat word om ooreenkomstig die gewone Imperiale voorwaardes en soldy weer by die R.F.C. aan te sluit.

d Alle range word opgeneem in die R.F.C. en sal, soos in soortgelyke ander eenhede, na verloop van tyd bevorderbaar wees.

e Alle kadette en ander range sal in die toekoms ooreenkomstig R.F.C.voorskrifte en -soldy gewerf word.

f Maj. Miller sal sy werwingsveldtog tot 31 Mei 1918 voortsit. Daarna sal dié sending tot die einde van die jaar aan die Unie onttrek word.

Hierdie besluite is aan die Unieregering meegedeel.

Ten slotte is daar nog 'n antwoord van die Departement van Verdediging op 'n skrywe van genl. Smuts (Londen). Hierdie skrywe is gedateer 24 April 1918 en uit die inhoud blyk dat m.b.t. ontslag van personeel, opdragte in Londen gegee sal word. 
Op 26 April 1918 was daar nog 20 lede van die Suid-Afrikaanse eskader (R.F.C.) wat nog nie ontslaan was nie. Hulle was hospitaalgevalle en personeel wat op verlof was as gevolg van siekte of herstel. Die laagste nommer van hierdie groepie was Z.338, t.w. 2e lugwerktuigkundige M. Vaughan, van wie die laaste maal op 7 Maart 1918 uit die militêre hospitaal op Wynberg verneem is en die hoogste, t.w. Z.571, manskap J. Stoker. Van hom, 'n invalide, is vir die laaste maal op 17 Januarie 1918 uit Nairobi verneem. 


\section{SUMMARY}

On 9 July, 1915, the Union Government made an offer to the Imperial Government to make available to the Government the entire South African Aviation Corps i.e. both personnel and equipment involved in the German South West African campaign. With this offer the history of the later 26 Squadron R.F.C./ R.A.F. under Major G. P. Wallace had its beginning. A number of officers of the S.A.A.C. left for England on 31 July, 1915. They were followed by other personnel in August. Towards the end of the same year the South African Squadron, which had been incorporated into the R.F.C. in 1915, was ready for service. An interesting official correspondence took place with reference to this occasion.

The equipment shipped to England on the termination of the campaign in German South West Africa led to a penetrating official investigation and later, in 1918, the Union government received compensation amounting to R20 400 in respect of six aircraft, twenty-two motor cars, seven motor cycles and a large volume of spare parts and accessories; these originally cost R52623.

Continuous recruiting campaigns in the Union ensured the continued existence of 26 Squadron which was known as the South African Squadron, R.F.C. (later R.A.F.). On 26 April, 1918, there were 20 South African volunteers and of which both the name and motto brought South Africa in mind. In reality 26 Squadron, as has been shown in this contribution, was a British squadron, thanking its origin to an offer by the Union government.
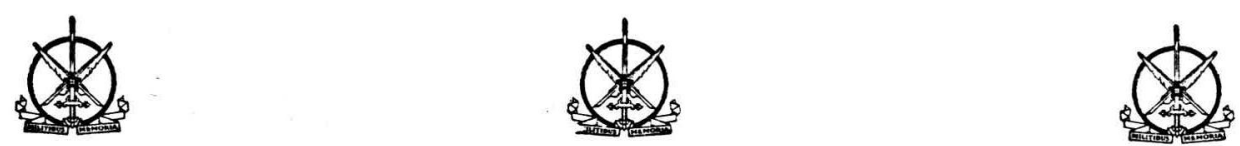


\section{Aantekeninge}

1 Per aspera ad astra, p 14.

2 Gedurende Mei en Augustus 1915 is die volgende standaarduitrusting aan die Z.A.V.K. uitgereik: 22 Studebaker-motors, 5 vliegtuig-sleepwaens, 7 motorfietse, voorrade e.d.m. met 'n totale waarde van R34 900. In Augustus 1915 is besluit dat onderdele, wat deur die Z.A.V.K. bestel en nog nie verskeep is nie, gelykop tussen die War Office en die Britse admiraliteit verdeel sal word.

3 In dieselfde telegram verklaar die Hoë Kommissaris dat senators Tucker, Papenfuss e.a. hul seuns as offisiere in die R.F.C. wil hê.

4 In sy telegram van 8.10 .1915 het genl. Smuts vermeld dat hy dalk kan kry: four coppersmiths, three sailmakers, two electricians, six riggers, 33 fitters and turners, four instrument repairers, 15 motor cyclists, 4 cooks. 24 radio-operateurs was nie beskikbaar nie. M.b.t. toelaes is in die persverklaring vermeld dat hulle dieselfde is as vir lede van die S.A. Oorsese Ekspedisiemagte.

5 Lt. John het besluit om nie na Engeland te gaan nie.

6 In die telegram aan genl. Smuts, 14.12.1915, is die range nie genoem nie.

7 Per aspera ad astra, p 15.

Percy Leonard Lindup is op 17.10.1887 in Kaapstad gebore. 26.10.1915 - 21t. Z.A.V.K. S.A. Eskader R.F.C. 8.11.1915 - Vertrek na Engeland. 1.4.1918-6.10.1919 - 2lt R.A.F., behou rang van kapt.. Dien gedurende W.O.II as maj. (waarn. lt./kol.). Is onthef op 25.11.1944. Ouderdomsgrens bereik op 17.10.1947.

Joseph Gerald Francis is op 17.8.1876 gebore. 30.10.1915 - 2lt. Z.A.V.K., op dieselfde dag gesekondeer na R.F.C. 7.11.1915 - Vertrek na Oos-Afrika. 8.4.1917 - Ingeskeep Dar-es-Salaam. 16.4.1917 - Ontskeep Durban. 26.4.1917 - Na Engeland. Lê kommissie neer ten tye van ontbinding Z.A.V.K. (30.9.1921).

George Altred Limouzin is op 16.12 .1885 te Moulmerin, Birma, gebore. Des. 1902Januarie 1906, lid Burmah Police. Maart 1906-Des. 1907 - Manskap Natal Carbineers. Aug. 1914-Junie 1915 - 1t. First City Regiment. Julie 1915-April 1916 - 1t. R.F.C. Mei 1916-Aug. 1919 - lt./kapt. Royal Artillery (Frankryk, Oos-Afrika).

Henry Vincent Batten. 26.1.1915 - 2lt. Z.A.V.K. 25.5.1915 - It./tydelike kapt./(as adj.). 26.1.1915-5.6.1915 - lt. 6.6.1915-18.9.1915 - kapt. Doen diens in Oos-Afrika t./lt. K. A. Rifles (21.2.1918-11.1.1919).

Aangaande maj. Henry Meintjes, M.C., A.F.C., is in The Star, Johannesburg, 26.5.1949, vermeld dat hy op Colesberg gebore is, aan die veldtog in S.W.A. deelgeneem en by die R.F.C. aangesluit het. Hy het o.m. teen Von Richthofen se eskader opgetree, is gewond maar het agter die linies geland en die M.C. en A.F.C. verwerf. As een van die staatmakers het hy op 20.1.1922 by die S.A.L.M. aangesluit Hy het in 1929 'n vliegtuig teen ruim $254 \mathrm{~km}$ per uur bestuur en in $8 \frac{1}{2} \mathrm{~min}$. tot ongeveer $3300 \mathrm{~m}$ gestyg. Maj. Meintjes is op 1.3.1931 na die S.A. Polisie oorgeplaas en is op 25.5.1949 op 58-jarige leeftyd op Johannesburg oorlede. (Sien ook: Rand Daily Mail, 31.5.1949).

8 Hierdie brief is op see geskrywe.

9 Die skrywe is November 1915 gedateer.

10 Vgl Per aspera ad astra, p 14, m.b.t. Oktober 1915 as inlywingsdatum.

11 U.G. $36-16$, p 173.

12 U.G. 41 - 17, p 165.

Die volgende besonderhede aangaande aankope is elders gevind. Op 1.6.1915: 4 vliegtuie sonder enjins - R8 400, op 23.6.1914: 2 vliegtuie sonder enjins - R4 200.

13 Rand Daily Mail, 10.11.1916; 15.11.1916: 27.11.1916, 24.11.1916.

14 Ibid., 29.8.1917.

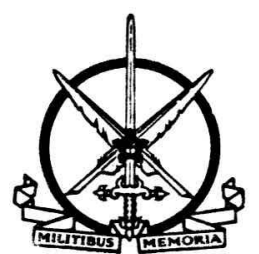

